\title{
Government Expenditures and Economic Growth: The Nigerian Experience
}

\author{
Robinson Monday Olulu (Ph.D) \\ Department of Economics, University of Port Harcourt \\ Eravwoke Kester Erhieyovwe (Ph.D) \\ Department of Economics, College of Physical Edu, Mosogar. Delta State \\ Ukavwe Andrew \\ Department of Economics, College of Education Warri, Delta State, Nigeria
}

Doi:10.5901/mjss.2014.v5n10p89

\begin{abstract}
The paper investigates the empirical relationship between government expenditure and economic growth. Government expenditure was disaggregated unto, total expenditure, public debt expenditure, expenditure on health and government expenditure on Education. The ordinary least square (OLS) was applied to ascertain the short-run relationship between variables, however, the Augmented Dickey Fuller (ADF) test, was used to examine long-run relationship between variables in the equation. Results of the test show that there is an inverse relationship between government expenditures on health and economic growth; while government expenditure on education sector, is seen to be insufficient to cater for the expending sector in Nigeria. It was also discovered that government expenditure in Nigeria could increase foreign and local investments. The paper recommended that government should spend more on key macro-variables, such as health, infrastructure, power, etc. This it is believed that judicious expenditure of government, will power the transformation agenda of government as well as engender growth in the Nigerian economy.
\end{abstract}

\section{Introduction}

The relationship between government expenditure and economic growth has continued to generate series of debate among scholars. Government performs two functions- protection (security) and provision of certain public goods (Abdullah, 2000 and Al-Yousif, 2000). Protection function consists of the creation of rule of law and enforcement of property rights. This helps to minimize risks of criminality, protect life and property, and the nation from external aggression. Under the provision of public goods are defense, roads, education, health, and power, to mention few. Some scholars argue that increase in government expenditure on socio-economic and physical infrastructures encourages economic growth. For example, government expenditure on health and education raises the productivity of labour and increase the growth of national output. Similarly, expenditure on infrastructure such as roads, communications, power, etc, reduces production costs, increases private sector investment and profitability of firms, thus fostering economic growth. Supporting this view, scholars such as Ranjan (2008), Cooray (2009) concluded that expansion of government expenditure contributes positively to economic growth. However, some scholars did not support the claim that increasing government expenditure promotes economic growth, instead they assert that higher government expenditure may slowdown overall performance of the economy. For instance, in an attempt to finance rising expenditure, government may increase taxes and/or borrowing. Higher income tax discourages individual from working for long hours or even searching for jobs. This in turn reduces income and aggregate demand. In the same vein, higher profit tax tends to increase production costs and reduce investment expenditure as well as profitability of firms. Moreover, if government increases borrowing (especially from the banks) in order to finance its expenditure; it will completely crowd-out the private sector, thus reducing private investment. Furthermore, in a bid to score cheap popularity and ensure that they continue to remain in power, politicians and government officials sometimes increase expenditure and investment in unproductive projects or in goods that the private sector can produce more efficiently. Thus, government activity sometimes produces misallocation of resources and impedes the growth of national output. In fact, studies by Laudau (1986), Barro (1991), and Engen, Skinner (1992), suggested that large government expenditure has negative impact on economic growth. In 
Nigeria, government expenditure has continued to rise due to the huge receipts from production and sales of crude oil, and the increased demand for public (utilities) goods like roads, communication, power, education and health.

Besides, there is increasing need to provide both internal and external security for the people and the nation. Available statistics show that total government expenditure (capital and recurrent) and its components have continued to rise in the last three decades. For instance, government total recurrent expenditure increased from N3, 819.20 million in 1977 to N4, 805.20 million in 1980 and further to N36, 219.60 million in 1990. Recurrent expenditure was N461, 600.00 million and N1, 589,270.00 million in 2000 and 2007, respectively. In the same manner, composition of government recurrent expenditure shows that expenditure on defense, internal security, education, health, agriculture, construction, and transport and communication increased during the period under review. Moreover, government capital expenditure rose from N5, 004.60 million in 1977 to N10, 163.40 million in 1980 and further to N24, 048.60 million in 1990. The value of capital expenditure stood at N239, 450.90 million and N759, 323.00 million in 2000 and 2007, respectively. Furthermore, the various components of capital expenditure (that is, defense, agriculture, transport and communication, education and health) also show a rising trend between 1977 and 2007. Unfortunately, rising government expenditure has not translated to meaningful growth and development, as Nigeria ranks among the poorest countries in the world. In addition, many Nigerians have continued to wallow in abject poverty, while more than 50 percent live on less than US $\$ 2$ per day. Couple with this, is dilapidated infrastructure (especially roads and power supply) that has led to the collapse of many industries, including high level of unemployment. Moreover, macroeconomic indicators like balance of payments, import obligations, inflation rate, exchange rate, and national savings reveal that Nigeria has not fared well in the last couple of years. (Olugbenga and Owoye, 2007). Given the issues raised above, this paper seeks to examine the effect of government expenditure on economic growth in Nigeria. The paper is divided into five sections, the first section is the introduction, the second is the literature review, the third section is model specification while the fourth section is data sources/analysis. The final section is the conclusion and recommendations.

\section{Review of Related Literature}

Numerous studies have been conducted to investigate the relationship between government spending and economic growth. Landau (1983) found that the share of government consumption to GDP reduced economic growth which was consistent with the pro-market view that the growth in government constrains overall economic growth. The conclusions were germane to growth in per capita output and do not necessarily lead to increase in economic welfare. Economic growth was also found to be positively related to total investment in education. In a later study, Landua (1986) extends the analysis to include human and physical capital, political, international conditions as well as a three year lag on government spending in GDP. Government spending was disaggregated to include investment, transfers, education, defense and other government consumption. The results in part mirrored the earlier studies in that general government consumption was significant and had a negative influence on growth. Education spending was positive but not significant. It was unclear why lagged variables were included given that the channels through which government influence growth suggest a contemporaneous relationship.

Ram (1986) study marked a rigorous attempt to incorporate a theoretical basis for tracing the impacts of government expenditure to growth through the use of production functions specified for both public and private sectors. The data spanned 115 countries to derive broad generalizations for the market economies investigated. He found government expenditure to have significant positive externality effects on growth particular in the developing countries (LDC) sample, but total government spending had a negative effect on growth. Lin (1994) used a sample of 62 countries (1960-85) and found that non-productive spending had no effect in growth in the advanced countries but a positive impact in LDCs. Other studies have investigated the impact of particular (functional) categories of public expenditure. For example, Deverajan et al (1993), using a sample of 14 OECD countries, found that spending on health, transport and communication have positive impacts whereas spending on education and defence did not have a positive impact. In the majority of studies, total government spending appears to have negative effect on growth (Romer, 1990; Alexander; 1990; Folster and Henrekson; 1999). Seymour et al. (1997) used a disaggregated approach to examine the impact of government expenditure on economic growth in the OECD.

Josaphat et al. (2000), investigated the impact of government spending on economic growth in Tanzania (19651996) using time series data for 32years. They formulated a simple growth accounting model, adapting Ram (1986) model in which total government expenditure is disaggregated into expenditure on (physical) investment, consumption spending and human capital investment. It was found that increased productive expenditure (physical investment) have a negative impact on growth and consumption expenditure relates positively to growth, and which in particular appears to be associated with increased private consumption. The results revealed that expenditure on human capital investment 
was insignificant in their regression and confirm the view that public investment in Tanzania has not been productive, as at when the research was conducted.

Nitoy et al. (2003) employed the same disaggregated approach as followed by Josaphat et al. (2000). They examined the growth effects of government expenditure for a panel of thirty developing countries (including Nigeria) over the decades of the 1970s and 1980s, with a particular focus on sectoral expenditures. The primary research results showed that the share of government capital expenditure in GDP is positively and significantly correlated with economic growth, but current expenditure is insignificant. The result at sectoral level revealed that government investment and total expenditures on education are the only outlays that remain significantly associated with growth throughout the analysis. Although public investments and expenditures in other sectors (transport and communication, defense) was found initially to have significant associations with growth, but do not survive when government budget constraint and other sectoral expenditures were incorporated into the analysis. Also private investment share of GDP was found to be associated with economic growth in a significant and positive manner.

Junko and Vitali (2008) investigate the impact of government expenditure on economic growth in Azerbaijan because of the temporarily oil production boom (2005) which caused exceptionally large expenditure increase aimed at improving infrastructure and raising incomes. Azerbaijan's total expenditure increased by a cumulative 160 percent in nominal value from 2005 to 2007 (i.e. from 41 percent of non-oil GDP to 74 percent) in their research reference which were made to Nigeria and Saudi Arabia (1970-89) who have also experienced oil boom and increased government expenditure over the years. The study simulated the neo-classical growth model tailored to the Azeri conditions. Their analysis suggested that the evaluated fiscal scenario poses significant risks to growth sustainability and historical experience indicates that the initial growth performance largely depends on the efficiency of scale-up expenditure. The study also sheds light on the risks associated with a sudden scaling-down of expenditure, including the political difficulties to undertake an orderly expenditure reduction strategy without undermining economic growth and the crowding out effects of large government domestic borrowing.

The recent revival of interest in growth theory has also revived interest among researchers in verifying and understanding the linkages between government spending and economic growth especially in developing country like Nigeria. Over the past decades, the public sector spending has been increasing in geometric term through government various activities and interactions with its Ministries, Departments and Agencies (MDA's), (Niloy et al. 2003). Although, the general view is that public expenditure either recurrent or capital expenditure, notably on social and economic infrastructure can be growth-enhancing although the financing of such expenditure to provide essential infrastructural facilities-including transport, electricity, telecommunications, water and sanitation, waste disposal, education and healthcan be growth retarding (for example, the negative effect associated with taxation and excessive debt). The size and structure of public expenditure will determine the pattern and form of growth in output of the economy. The structure of Nigerian public expenditure can broadly be categorized into capital and recurrent expenditure. The recurrent expenditure are government expenses on administration such as wages, salaries, interest on loans, maintenance etc., whereas expenses on capital projects like roads, airports, education, telecommunication, electricity generation etc., are referred to as capital expenditure. One of the main purpose of government spending is to provide infrastructural facilities

The relationship between government spending on public infrastructure and economic growth tends to be an important analysis in developing countries, most of which have experienced increasing levels of public expenditure overtime (World Development Report, 1994). Expenditure on infrastructure investment and productive activities (in StateOwned Enterprises) ought to contribute positively to growth, whereas government consumption spending is anticipated to be growth-retarding (Josaphat and Oliver, 2000). However, economies in transition do spend heavily on physical infrastructure to improve economic welfare of the people and facilitate production of goods and services across all sectors of the economy so as to stimulate rapid growth in aggregate output. Empirical studies (Ram, 1986; Deverajan et al., 1993; Nitoy et al., 2003) have found that there exists positive correlation between economic growth and public spending on infrastructural facilities. Manufacturing industries do consider infrastructure services or facilities before locating their production base in order to gain large economies of scale and reduce cost of production. Also, to increase total industrial output at a cheaper price in the economy.

Following the World Bank's Development Report (1994), developing countries invest \$200billion a year in new infrastructure representing 4 percent of their national output and a fifth of their total investment. The result has been a dramatic increase in infrastructure services-for transport, power, water, sanitation, telecommunications, and irrigation. The provision of infrastructure services to meet the demands of business, households, and other users is one of the major challenges of economic development in developing countries like Nigeria. 


\section{Model Specification}

$\mathrm{GDP}=\mathrm{f}(\mathrm{TGE}, \mathrm{PDS}, \mathrm{HLT}, \mathrm{EDU})$

In econometrics equation (1) can be transformed as:

$G D P=a_{0}+a_{1} T G E+a_{2} P D S+a_{3} H L T+a_{4} E D U+\partial_{t}$

Apriori; $\mathrm{TDS}<0$, PDS $>0, \mathrm{HLT}>0$, EDU $>0$

Where:

GDP $=$ Gross Domestic Product

TGE = Total Government Expenditure

PDS = Public Debt Service

$\mathrm{HLT}=$ Government Expenditure in Health

$\mathrm{EDU}=$ Government Expenditure on Education
(1)

\section{Data Sources/Analysis}

This study set up an econometric model to test the long run relationship between government expenditures and the growth of the Nigerian economy. The study uses annual time series data from 1980 to 2010. The sources of these data central Bank of Nigeria statistical bulletin, several issues, Bureau of Statistics, journals etc.

The study tests for the order of integration of the variables, i.e. the stationarity of the variables. Augmented Dickey Fuller (ADF) test for stationarity is applied to know the order of integration of the variables in the model. The parameter of the co integrating equation is used to purge the trend from the linear combination of the variables.

Table 1 shows the short run relationship between government expenditure, public debt service, expenditure on Health Sector, education and Economic Growth in the Nigerian.

Table 1: Short Run Regression Analysis

\begin{tabular}{|ccccc|}
\hline Variable & Coefficient & T-statistics & Prob & $\mathbf{R}^{2}=\mathbf{0 . 9 7 2 8 8 0}$ \\
\hline \hline TGE & 0.102598 & 3.611481 & 0.0013 & AdjR2 $=0.968541$ \\
PDS & 0.297060 & 3.926613 & 0.0006 & F.stat $=224.2101$ \\
HLT & -1.080365 & -0.885649 & 0.3842 & D.W. stat. 1.280983 \\
EDU & 1.034954 & 1.687635 & 0.1039 & \\
t & 217760.2 & 27.57084 & 0.000 & \\
\hline
\end{tabular}

Source: Author's computation

Table 2: ADF Unit Root Result

\begin{tabular}{||cccc|}
\hline \hline Variables & Level & First Difference & Integration Order \\
\hline \hline TGE & 0.223572 & -2.965139 & $I(I)$ \\
PDS & -0.245301 & -4.082407 & $\mid(I)$ \\
HLT & 2.126430 & -3.187158 & $\mid(I)$ \\
EDU & 1.131394 & -3.601973 & $I(I)$ \\
\hline
\end{tabular}

$1 \%$ critical value $-3.6959,5 \%$ critical value $-2.975010 \%$ critical value -2.6265

Table 3: Result of Johansen Co-integration Test Result

Test assumption: Linear deterministic trend in the Data

Series : GDP TGE PDS HLT EDU

Lags Interval: 1 to I

\begin{tabular}{||ccccc||}
\hline Eigenvalue & Likelihood Ratio & 5 Percent critical value & 1 Percent critical value & Hypothesized No. of CE(S) \\
\hline \hline 0.868988 & 123.5940 & 68.52 & 76.07 & None $^{\star \star \star}$ \\
0.692955 & 66.68505 & 47.21 & 54.46 & At most 1 ${ }^{\star *}$ \\
0.473172 & 33.62375 & 29.68 & 35.65 & At most 2 \\
0.333395 & 15.67909 & 15.41 & 20.04 & At most 3 $^{*}$ \\
0.143079 & 4.323462 & 3.76 & 6.65 & At most 4 $^{*}$ \\
\hline
\end{tabular}

$\left.{ }^{*}(*)\right)$ Denotes rejection of the hypothesis at $5 \%(1 \%)$ significance level L.R test indicates 5 cointegrating equation(s) at $5 \%$ significance level. 
Table 4: Summary of Over Parameterized ECM Model

\begin{tabular}{|c|c|c|c|c|}
\hline \multicolumn{5}{|c|}{$\begin{array}{l}\text { Dependent Variable: GDP } \\
\text { Method: Least Squares } \\
\text { Date: } 26 / 29 / 05 \text { Time: } 00.45 \\
\text { Sample(adjusted): } 19842010 \\
\text { Included observations: } 27 \text { after adjusting endpoints }\end{array}$} \\
\hline Variable & Coefficient & Std. Error & t-Statistic & Prob. \\
\hline T TGE & -0.007786 & 0.028636 & -0.271892 & 0.7918 \\
\hline TGE $(-1)$ & 0.074968 & 0.071190 & 1.053078 & 0.3198 \\
\hline TGE $(-2)$ & -0.174422 & 0.044851 & -3.888898 & 0.0037 \\
\hline TGE(-3) & 0.043828 & 0.136075 & 0.322086 & 0.7547 \\
\hline PDS & -0.027627 & 0.123450 & -0.223793 & 0.8279 \\
\hline PDS(-1) & 0.029256 & 0.102071 & 0.286628 & 0.7809 \\
\hline $\operatorname{PDS}(-2)$ & 0.066665 & 0.168823 & 0.394877 & 0.7021 \\
\hline PDS(-3) & 0.041139 & 0.172538 & 0.238431 & 0.8169 \\
\hline $\mathrm{HLT}$ & 0.314767 & 2.485398 & 0.126646 & 0.9020 \\
\hline $\mathrm{HLT}(-1)$ & -2.800743 & 1.460172 & -1.918090 & 0.0873 \\
\hline HLT(-2) & 0.113654 & 1.303505 & 0.087191 & 0.9324 \\
\hline $\operatorname{HLT}(-3)$ & -3.842547 & 2.507126 & -1.532650 & 0.1597 \\
\hline EDU & -0.019724 & 1.410210 & -0.013987 & 0.9891 \\
\hline $\operatorname{EDU}(-1)$ & 2.874530 & 0.954209 & 3.012474 & 0.0147 \\
\hline EDU(-2) & 2.123247 & 1.480471 & 1.434170 & 0.1853 \\
\hline $\operatorname{EDU}(-3)$ & 2.660813 & 1.088920 & 2.443534 & 0.0371 \\
\hline ECM(-1) & 0.920034 & 0.158606 & 5.800743 & 0.0003 \\
\hline $\mathrm{C}$ & 237636.6 & 5539.871 & 42.89569 & 0.0000 \\
\hline R-squared & 0.998554 & \multicolumn{2}{|c|}{ Mean dependent var } & 372861.4 \\
\hline Adjusted R-squared & 0.995823 & \multicolumn{2}{|c|}{ S.D. dependent var. } & 166937.0 \\
\hline S.E. of regression & 10788.68 & \multicolumn{2}{|c|}{ Akaike infor criterion } & 21.64510 \\
\hline Sum squared resid & $1.05 \mathrm{E}+09$ & \multicolumn{2}{|c|}{ Schwarz criterion } & 22.50899 \\
\hline Log likelihood & -274.2089 & \multicolumn{2}{|c|}{ F-statistic } & 365.6494 \\
\hline Durbin-Watson stat. & 2.062431 & \multicolumn{2}{|c|}{ Prob(F-statistic) } & 0.000000 \\
\hline
\end{tabular}

Table 5: Parsimonious Error Correction Model

\begin{tabular}{|c|c|c|c|c|}
\hline \multicolumn{5}{|c|}{\begin{tabular}{|l|} 
Dependent Variable: GDP \\
Method: Least Squares \\
Date: $26 / 29 / 05$ Time: 00.59 \\
Sample(adjusted): 19842010 \\
Included observations: 27 after adjusting endpoints
\end{tabular}} \\
\hline Variable & Coefficient & Std. Error & t-Statistic & Prob. \\
\hline TGE & 0.105818 & 0.013173 & 8.033218 & 0.0000 \\
\hline TGE(-2) & 0.025182 & 0.013548 & 1.858786 & 0.0816 \\
\hline PDS & 0.135134 & 0.040089 & 3.370856 & 0.0039 \\
\hline HLT & -0.058768 & 0.667728 & -0.088011 & 0.9310 \\
\hline $\mathrm{HLT}(-1)$ & 1.570811 & 0.587730 & 2.672675 & 0.0167 \\
\hline $\operatorname{HLT}(-3)$ & -1.026472 & 0.675707 & -1.519108 & 0.1482 \\
\hline EDU & 0.843911 & 0.290247 & 2.907563 & 0.0103 \\
\hline $\operatorname{EDU}(-1)$ & -0.627800 & 0.403351 & -1.556460 & 0.1392 \\
\hline $\operatorname{EDU}(-3)$ & -0.574352 & 0.323563 & -1.775087 & 0.0949 \\
\hline ECM & 0.945606 & 0.072502 & 13.04245 & 0.0000 \\
\hline $\mathrm{C}$ & 227204.9 & 2964.008 & 76.65462 & 0.0000 \\
\hline R-squared & 0.998182 & \multicolumn{2}{|c|}{ Mean dependent var } & 372861.4 \\
\hline Adjusted R-squared & 0.997045 & \multicolumn{2}{|c|}{ S.D. dependent var. } & 166937.0 \\
\hline S.E. of regression & 9074.178 & \multicolumn{2}{|c|}{ Akaike infor criterion } & 21.35582 \\
\hline Sum squared resid & $1.32 \mathrm{E}+09$ & \multicolumn{2}{|c|}{ Schwarz criterion } & 21.88375 \\
\hline Log likelihood & -277.3036 & \multicolumn{2}{|c|}{ F-statistic } & 878.3623 \\
\hline Durbin-Watson stat. & 2.179808 & \multicolumn{2}{|c|}{ Prob(F-statistic) } & 0.000000 \\
\hline
\end{tabular}




\section{Conclusion and Policy Recommendations}

It is discovered that enhanced government expenditures will increase inflow of better living, inflow of foreign and local businessmen and relevant capital that will enhance growth and development of an economy.

The work equally discovered that there is inverse relationship between government expenditures on health sector and economic growth in Nigeria. This implies that the expenditures of the Nigerian government on the health sector are not enough to transform the gross domestic product of the Nigerian economy. It is also discovered that there exists a long-run relationship between government expenditures and economic growth in Nigeria. Thus, we conclude that expenditures on educational sector in Nigeria is not large enough to transform into growth and development of the nation and this can be seen as the reason why various union like ASSU, COEASUU etc are always going on strike.

The policy implication of the result of the study is that the government should have more expenditure on key macro economic variables in order to transform effective and efficient growth of the Nigerian economy. It will also save persistent strike of various unions in the economy. Our government should spend more money on the health sector to increase our life expectancy ratio.

\section{References}

Almed, J. and S. Harnhinen, (1995). Unit Roots and Cointegration in estimating Causality between Exports and Economic Growth: Empirical Evidence from the ASIAN Countries. Economic Letters, 49:320-334.

Engel, R. F. and C. W. J., Granger (1987). Co-integration and Error Correction: Representation, Estimation and Testing. Econometrica, 55:251-276.

Eravwoke, K. and Imide, I. (2013). Consumption, Foreign Direct Investment and its Impacts on Exchange Rate of the Nigerian Economy. Mediterranean Journal of Social Sciences. Pp. 345-350.

Kareem, O. I. (2005). Pension Reform and Public Workers' Welfare: An Econometric Analysis: Annual Conference of the Nigerian Economic Society pp. 297-330.

Nelson, C. F. and C. I. Plosser (1982). Trends and Random walks Consumption Function: An Interpretation of Gross Data. PostKeynesian Economics, K. K. Krilbara, Ed., New Brunswick, N. J. Rutgers University Press.

Kneller R, Bleaney M, Gemmell N, 1999. Fiscal Policy and Growth: Evidence from OECD Countries. Journal of Public Economics, 74: 171-190.

Barro R, 1990. Government Spending in a Simple Model of Endogenous Growth. Journal of Political Economy, 98(5):103-125.

Barro R, Sala-i-Martin X, 1992. Public Finance in Models of Economic Growth. Review of Economic Studies, 59: 645-661.

Easterly W, Rebelo S, 1993. Fiscal Policy and Economic Growth: An Empirical Investigation. Journal of Monetary Economics, 32: 417458. 